\title{
An Evaluation of Factors Affecting Brand Awareness in the Context of Social Media in Malaysia
}

\author{
Somayeh Shojaee ${ }^{1}$ \& Azreen bin Azman ${ }^{1}$ \\ ${ }^{1}$ Faculty of Computer Science and Information Technology, Universiti Putra Malaysia, Serdang, Malaysia \\ Correspondence: Somayeh Shojaee, Faculty of Computer Science and Information Technology, Universiti Putra \\ Malaysia, 43400 UPM Serdang, Selangor, Malaysia. Tel: 60-17-314-5278. E-mail: somayeh.shojaee@gmail.com
}

\author{
Received: May 29, 2013 Accepted: September 18, 2013 Online Published: November 29, 2013 \\ doi:10.5539/ass.v9n17p72 URL: http://dx.doi.org/10.5539/ass.v9n17p72
}

\begin{abstract}
Living in the middle of a global communication boom with vast usage of social media, the business environment has become more complicated. So, it is more difficult for marketers to create and increase brand awareness as they have to be able to coordinate messages and efforts across all the existing media to capture customers. Therefore, marketers have to consider these communication tools on branding process in the current competitive market-space. The purpose of this study is to evaluate the factors affecting on brand awareness through social media in Malaysia. Data for this study was obtained from 391 students of Universiti Putra Malaysia. The results indicate customer engagement, brand exposure, and electronic-word-of-mouth have positive correlation with brand awareness in the context of social media and the most effective factor is customer engagement. The study recommends that brands will be profited from social media in order to create and enhance brand awareness and the benefits will be mostly increased by using this media's interactivity features to tie customers more closely to a brand.
\end{abstract}

Keywords: brand awareness, brand exposure, customer engagement, electronic-word-of-mouth, social media

\section{Introduction}

Marketing communication channels are the means for companies to notify, remind, and convince customers about their brands, products or services (Kotler \& Keller, 2009), but choosing efficient means to carry the message is difficult. The advent of the Internet has created new avenues for finding customer; specially using social media channels to find and maintain customers are new challenge of marketers.

Social media consists of various forms such as forums, blogs, micro blogging, social networks, media sharing sites, virtual worlds, social bookmarking, voting sites (Weber, 2009) message boards, wikis, and podcasts (Evans, 2008). Social media is playing an important role in people's daily life and also in businesses. Looking at the vast penetration of social media and the projected number of active users in the future, we can expect companies to be more and more involved in the use of social media (Kichatov \& Mihajlovski, 2010).

In comparison between social media, and traditional media, the former provides an interactive communication among customers and brands by allowing them to talk and share information via the web (Carlsson, 2010). Social media allow quick response to customer service issues by having the chance to hear good or bad news quickly (Brown, 2010), facilitating interactions, and sharing of contents (Palmer \& Koenig-Lewis, 2009) in a fast, wide spread, viral, and low-cost way (Miller et al., 2009; Stokes, 2008).

Since the advent of social media, the marketing funnel has been dramatically transformed from the simple to a highly complicated form (Haven et al., 2007). Improving the level of brand awareness is one of the marketers' challenges as reflected in the complicated funnel. To achieve the different levels of brand awareness, recognition, recall, top of the mind and dominant, brands need to make a strong association with customers. Based on the existing researches, Brand Exposure, Customer Engagement and Electronic-Word-Of-Mouth are the factors to evaluate the impacts of social media on brand awareness.

Brand Exposure-In building a brand, after finding the target audience, the brand should start to disclose itself by using some strategies; this act is called "Brand Exposure" (Gole, 2009). Exposing the brand assists customers to focus on small selected of brands for products or services which are in demand.

"Mere Exposure Theory" (Zajonc, 1968) is a potential theory for describing brand exposure relationship with 
brand awareness. The effect of mere-exposure is a psychological phenomenon by which individuals who are given a stimulus would develop a priority for people or things that are more familiar to them. This theory is used to explain communication impacts in kind of low information circumstance (Grimes, 2008; Matthes et al., 2007).

During a psychological and intellectual procedure the favorable impression is developed on people's minds due to the familiarity with the object created by the exposure. Brand exposure can shape non-consumer behavior through cognitive mechanisms, because it can shape non-conscious behavior (Fitzsimon et al., 2008). Based on this theory the unintentional participation procedures occur in most of the marketing communications tools to reveal a brand, such as advertising in social media (Cianfrone et al., 2008). Brand exposure enhances brand awareness (Cornwell et al., 2000; Pitts \& Slattery, 2004), purchasing intention and the brand attitude (Laroche et al., 1996).

There are several successful cases about social media usages for brand exposure that one of them is the Fiesta-Movement for Ford U.S. to expose its new product. It was great for the Ford due to making a lot of free advertising, through social media by people, and absorbing the people's attention to this brand, selling 10,000 cars in six days and creating brand awareness for the Fiesta as a new product (Poffé, 2010).

Customer Engagement-New complicated marketing funnel provides capabilities for contributors to create brand awareness. For instance, an individual customer, who may not buy a lot, but always rates and makes reviews, can influence many other potential or existing buyers (Haven et al., 2007). Hence, marketers require new perspective to the brand awareness characterized by social media, which is called engagement.

Bond (2010) applied, the Use-and-Gratification theory (U\&G theory) (Calder et al., 2009) to explain the precedents and outcomes of engagement in social media, which contribute its credibility for investigating the behaviors in social media context. She found a model for customer engagement with brands toward social media and outcomes of engagement such as brand awareness.

Engaged users and brands become members of a community/group who share their interest with each other. Memorability of the brand which is maximized if the amounts of cognitive effort people spend during the processing are maximized. Consequently, the chance of remembering a brand later on is maximized too, in the form of recall or recognition (Plummer et al., 2007).

Hollebeek (2011) defines customer engagement with a brand as a mixture of intellectual and emotional interactions characterizing customer's contextual and brand-related state of mind. In fact, engagement contains four components an individual can experience with a brand over time as the following involvement, interaction, intimacy, and influence (Haven et al., 2007). When a brand shares a picture, video or updating its status, the fans quickly think and talk about them, so brands can involve their customer easily and quickly (Manning-Schaffel, 2009). Engagement among customers and a brand has positive effects on service quality and customer satisfaction by getting customers' feedback (Moorthi, 2002). Also, this interactive media enhances message credibility and a sense of involvement (Bhattacharya \& Sen, 2003).

Statistics show high level social media engagement among people and brands. As an example, around $70 \%$ of U.S. online adults have been involved in at least one of the activities such as commenting on product reviews sites or blogs, attending online discussion boards/forums (Plummer et al., 2007). A research indicates that 37\% of $18-26$ year olds and $31 \%$ of $27-40$ year olds like to view advertiser's profiles and share them with others $(\mathrm{Li}$, 2007).

Electronic-Word-of-Mouth-Electronic-WOM was born with the advent of computer-generated mediums and is the extension of WOM (Dellarocas, 2003). E-WOM is many-to-many communication and receiver and senders do not know each other. However, in case of trusted websites the effects of e-WOM is high because of the number of people that involved in a discussion. E-WOM helps marketers to reduce their cost of advertising, because transferring a good experience is more effective than advertising. Customers believe messages from other customers rather than messages from the company itself (Jansen et al., 2009).

According to Integrating Marketing Communications Model (Kotler \& Keller, 2009) for building brand equity and the extended model by Xu and Chan (2010), WOM (e-WOM) has a direct relationship to brand awareness. When a person has strong intention to a brand or a product, social media allows him to communicate and transfer his thoughts from a few people to the whole world (broad spread) very quickly. E-WOM can be a powerful tool to promote a brand, which can be used as one of the advertising tools such as recommending a brand from the fan page of a brand to others who may not be aware of the brand (Weber, 2009).

Social media interactivity leads to the increase of the credibility of e-WOM because of high transparency of the information (Bickart \& Schindler, 2001) which causes higher credibility of social media in comparison to 
traditional media. E-WOM in compare to other types of marketing communication mix is faster, broader, and easier with exponential progress (Thackeray et al., 2008). E-WOM assists and encourages customers to pass the message of the marketers or products' information. A successful example of e-WOM is the Georgetown Cupcake. After only two weeks, it sold 800 cupcakes per day without any advertising only by posting review comments (Nicholls, 2008).

Given the vast progress and importance of social media on businesses, the research is somewhat lagging behind this rapid development. It is difficult to find relevant and up to date studies on how social media is to be a part of the brand awareness process, and how this media influence brand exposure, customer engagement and electronic-word-of-mouth to make and increase brand awareness. Hence, this study is designed to evaluate the impacts of social media on brand awareness.

\section{Materials and Methods}

Regarding the purpose of this study, data was collected by distributing questionnaire among students of Universiti Putra Malaysia (UPM) with different gender and age, levels of education, profession, and computer knowledge. A self-designed questionnaire has been considered for data collection. The questionnaire and its validity has been measured and guaranteed by academic and industrial practitioners. Participants have required to answer each item using six-point Likert scale, ranging from $6=$ strongly agree to $1=$ strongly disagree.

Bentler and Chou (1987) proposed that, under a normal distribution model, the relative ratio of the sample size to the number of free parameters should reach minimum 5:1, for the parameter estimations to be valid. Baumgartner and Homburg (1996) suggested that the ratio should be at least 10:1 for obtaining trustworthy significance tests. Therefore, 50 items have been adapted. To conduct the pilot study, fifty people participated and forty three attendants answered all the questions completely. To test reliability of the questions and measure of internal consistency, the Cronbach's Alpha method is used (Table 1).

Table 1. Cronbach's alpha test

\begin{tabular}{ll}
\hline Variable & Cronbach's Alpha \\
\hline Brand Exposure & 0.832 \\
Customer Engagement & 0.923 \\
Electronic-WOM & 0.9 \\
Brand Awareness & 0.893 \\
\hline
\end{tabular}

The values of the Cronbach's Alpha for the independent variables, including brand exposure, customer engagement and e-WOM, are obtained as $0.832,0.923$ and 0.9 respectively, and for the dependent variable, namely brand awareness, as 0.893 . The result highly confirms the internal consistency of the constructs and hence the reliability of the questionnaire, recalling the fact that the value 0.70 or higher is advised as acceptable in most social science studies.

After evaluating reliability of the questionnaire, it was distributed among the 500 UPM's students; however, only 391 complete responses were used for statistical analysis that they were appropriate for obtaining trustworthy significant tests for the highest 50 parameters of one model used in this research. The SPSS software was used as a statistic tool to analyze the data.

\section{Results}

Table 2 shows the characteristics of the sample based on the demographic information of participants. In term of gender, the percentage of female and male is $60.1 \%$ and $39.9 \%$ respectively. Looking at the age category, the data displayed high majority of respondents were under 24 years old, $55.2 \%$ and the next highest age category is between 25-34 years old, 36.6\%, and a small portion of participants were older than 34 years old. In terms of education level, $50.9 \%$ of respondents were bachelor, $33.5 \%$ were master, $9.2 \%$ of them Ph.D. and the rest was diploma students. The time of Internet usage per day was 5-7 hours with $25.8 \%, 2-5$ hours with $23.3 \%$, less than 2 hours amounted to $18.7 \%$ and the rests spent more than 7 hours per day. 
Table 2. Respondents' demographic profile

\begin{tabular}{|c|c|c|}
\hline Characteristics & Number & Percentage \\
\hline \multicolumn{3}{|l|}{ Gender } \\
\hline Female & 235 & 60.1 \\
\hline Male & 156 & 39.9 \\
\hline \multicolumn{3}{|l|}{ Age } \\
\hline 24 or under & 216 & 55.2 \\
\hline $25-34$ & 143 & 36.6 \\
\hline $35-44$ & 12 & 3.1 \\
\hline $45-54$ & 7 & 1.8 \\
\hline $55-64$ & 6 & 1.5 \\
\hline 65 or older & 7 & 1.8 \\
\hline \multicolumn{3}{|l|}{ Education Level } \\
\hline Diploma Student & 25 & 6.4 \\
\hline Bachelor Student & 199 & 50.9 \\
\hline Master Student & 131 & 33.5 \\
\hline MPhil/ PhD Student & 36 & 9.2 \\
\hline \multicolumn{3}{|l|}{ Average time spent online per day } \\
\hline Less than 2 hours & 73 & 18.7 \\
\hline 2 to 5 hours & 91 & 23.3 \\
\hline 5 to 7 hours & 101 & 25.8 \\
\hline 7 to 10 hours & 50 & 12.8 \\
\hline 10 to 14 hours & 38 & 9.7 \\
\hline More than 14 hours & 38 & 9.7 \\
\hline
\end{tabular}

To investigate the objectives of this research study, the relationship between the dependent variable and the independent variables, Multiple Linear Regressions were used. The dependent variable is Brand Awareness (Y) and three independent variables are Brand Exposure $\left(\mathrm{X}_{1}\right)$, Customer Engagement $\left(\mathrm{X}_{2}\right)$ and Electronic-Word-Of-Mouth $\left(\mathrm{X}_{3}\right)$. These variables are used in the multiple linear regression models:

$$
Y=\beta_{0}+\beta_{1} X_{1}+\beta_{2} X_{2}+\beta_{3} X_{3}+e \quad(e \text { is the error term })
$$

Table 3. Model summary

\begin{tabular}{lllll}
\hline $\mathbf{R}$ & $\mathbf{R}$ Square & Adjusted R Square & Std. Error of the Estimate & Durbin-Watson \\
\hline $.757^{\mathrm{a}}$ & .573 & .570 & .56622 & 1.872 \\
a. Predictors: (Constant), Brand Exposure, Customer & Engagement, E-WOM \\
b. Dependent Variable: Brand Awareness & \\
\hline
\end{tabular}

Table 3 presents the output model summary, to present the strength of the relationship between the independent variables of multiple regressions and the dependent variable which is measured by the relation R. Regarding the results of analysis, $\mathrm{R}=0.757$ which shows a reasonable positive correlation. The $\mathrm{R}$ Square value $(=0.573)$ shows the independent variables explain $57.3 \%$ of the variance in adoption. It means about $57.3 \%$ of the variation in brand awareness can be described by the variation in brand exposure, customer engagement and e-WOM.

The Durbin Watson statistics is used for indicating variables that do not have autocorrelation problems. According to Shim (2000), the values that fall within the range of 1.5 to 2.5 are favorable. The Durbin-Watson index is at 1.872, so the assumption of independence of error is not violated and no autocorrelation problem is happened. 
Table 4. ANOVA

\begin{tabular}{llllll}
\hline Source & Sum of Squares & df & Mean Square & F & P \\
\hline Regression & 166.538 & 3 & 55.513 & 173.148 & $.000^{\mathrm{a}}$ \\
Residual & 124.075 & 387 & .321 & & \\
Total & 290.613 & 390 & & & \\
a. Predictors: (Constant), E-WOM, Customer Engagement, Brand Exposure & & \\
b. Dependent Variable: Brand Awareness & & & \\
\hline
\end{tabular}

In Table 4, the ANOVA gives information about levels of variance within a regression model which is used for tests of coefficients' significance. One-way ANOVA analysis, shows that acceptance of brand awareness toward social media is statistically significant, because F-value is statistically significant, $F(3,387)=173.148$. The $\mathrm{p}$-value is less than $0.05(\mathrm{P}=0)$ which means that at least one of the three predictor variables can be used to model brand awareness.

Table 5. Model coefficients

\begin{tabular}{llllll}
\hline Predictors & Coefficients & Std. Error & t & Sig. & VIF \\
\hline (Constant) & 1.013 & .166 & 6.088 & .000 & \\
Brand Exposure & .153 & .061 & 2.517 & .012 & 2.167 \\
Customer Engagement & .381 & .043 & 8.921 & .000 & 2.103 \\
e-WOM & .289 & .053 & 5.496 & .000 & 2.502 \\
a. Dependent Variable: Brand Awareness & & & & \\
\hline
\end{tabular}

The coefficient test is used to find the most effective independent variable(s). According to the result (Table 5), the estimated multi regression model is formulated as

$$
\ddot{Y}=1.013+0.153 X_{1}+0.381 X_{2}+0.289 X_{3}
$$

According to the equation, the highest coefficient is possessed by customer engagement which is equal to 0.381 with highest $t$-statistic (8.921) and $p$-value of 0.000. And, brand exposure has the lowest coefficient with weight 0.153. It shows that one standard deviation increase in customer engagement is followed by 0.381 standard deviation increase in brand awareness, provided that the brand exposure and e-WOM are left unchanged. It can be explained for both other independent variables in the same way.

Based on the VIF values of the independent variables, there is no multicollinearity problem in the data, because none of the VIF values are around or greater than 5. Therefore, this model can be used for an estimation objective.

\section{Discussion}

The main objective of this research study is to assess the impact of social media on brand awareness by evaluating three factors, brand exposure, customer engagement and electronic-word-of-mouth. It was revealed from the study that social media positively influence the brand awareness. Parameters' estimation for the model was measured at significance level of 5\%. The results of this study are consistent with previous studies.

Positive impact of brand exposure was proved and confirmed by Mere Exposure Theory (Zajonc, 1968) and previous researches such as Fitzsimon et al. (2008). This theory explains that the unintentional participation procedures happen in majority of the marketing communications tools to expose a brand (Cianfrone et al., 2008).

Keller's (2009) research indicates that customer engagement increases brand awareness during the information gathering process. In Bond's model (2010), the Use-and-Gratification Theory indicates the brand awareness is one of the outcomes of customer engagement in the context of social media (Bond, 2010). This study too found that the most effective variable on brand awareness is customer engagement because it maximizes awareness during involvement and interaction processes.

Kotler and Keller's (2009) Integrating Marketing Communications Model for building brand equity, and also the extended model by $\mathrm{Xu}$ and Chan (2010), display the relationship between e-WOM and brand awareness. E-WOM transfer information from one customer to another and social media's interactive features help 
customers to share their thoughts rapidly and vastly.

\section{Conclusion}

This study attempts to assess the impacts of social media on brand awareness. The results illustrate that social media positively influence brand awareness because all three examined factors, brand exposure, electronic-word-of-mouth and customer engagement positively influence brand awareness, and customer engagement has greater impact among them. Based on the results, it can be concluded that the use of social media for the purpose of creating and enhancing brand awareness is essential and should be a part of marketers' strategies. According to the results of this research, additional studies are required to evaluate those factors by considering more details such as brand exposure frequencies' effects for better evaluation. This study could be useful for contributing to new studies on brand awareness for the industry or/and academic research purposes.

\section{Limitation and Future Research Recommendations}

Based on the limitations of this study such as population, further researches are required for more in-depth understanding of this new media on marketing funnel. Future research can be done on measuring other factors that may influence brand awareness toward social media, finding the impacts of e-WOM by considering positive and negative e-WOM on brand awareness, and investigating a research to compare the efficiency of social media and traditional media on brand awareness.

\section{Acknowledgments}

This work is partially supported by the Universiti Putra Malaysia, Research University Grant Scheme (RUGS) number 05-02-12-2153RU.

\section{References}

Baumgartner, H., \& Homburg, C. (1996). Applications of structural equation modeling in marketing and consumer research: a review. Int J. Res Mark, 13, 139-161. http://dx.doi.org/10.1016/0167-8116(95)00038-0

Bentler, P. M., \& Chou, C. P. (1987). Practical issues in structural modelling. Sociological Methods \& Research, 16(1), 78-117. http://dx.doi.org/10.1177/0049124187016001004

Bhattacharya, C. B., \& Sen, S. (2003). Consumer-Company Identification: A Framework for Understanding Consumers' Relationships with Companies. Marketing Journal, 67(April), 76-88. http://dx.doi.org/10.1509/jmkg.67.2.76.18609

Bickart, B., \& Schindler, R. M. (2001). Internet forums as influential sources of consumer information. Interactive Marketing Journal, 15(3), 31-40. http://dx.doi.org/10.1002/dir.1014

Bond, C. (2010). Engagement with social media and outcomes for brands: A conceptual framework. ANZMAC Annual Conference 2010, Christchurch, New Zealand.

Brown, C. H. (2010). 101 ways to promote your brand with social media marketing. Retrieved from http://webmarketing-coach.com/101SMM.pdf

Calder, B. J., Malthouse, E. C., \& Schaedel, U. (2009). An Experimental Study of the Relationship between Online Engagement and Advertising Effectiveness. Interactive Marketing Journal, 23(4), 321-331. http://dx.doi.org/10.1016/j.intmar.2009.07.002

Carlsson, L. (2010). Marketing and communications in social media: fruitful dialogue, stronger brand, increased sales (1st ed.). Gothenburg: Kreafon.

Cianfrone, B. A., Zhang, J. J., Trail, G. T., \& Lutz, R. J. (2008). Effectiveness of sport video games in game advertising: An experimental inquiry on current gamers. International Journal of Sport Communication, 1(2), 195-218.

Cornwell, T. B., Relyea, G. E., Irwin, R. L., \& Maignan, I. (2000). Understanding long-term effects of sports sponsorship: Role of experience, involvement, enthusiasm and clutter. International Journal of Sports Marketing \& Sponsorship, 2(2), 127-142.

Dellarocas, C. (2003). The digitization of WOM: Promise and challenges of online feedback mechanisms. Management Science Journal, 49(10), 1407-1424. http://dx.doi.org/10.1287/mnsc.49.10.1407.17308

Evans, D. (2008). Social media marketing-An hour a day. Wiley Publishing, Inc., Indianapolis, Indiana.

Fitzsimons, G. M., Chartrand, T. L., \& Fitzsimons, G. J. (2008). Automatic effects of brand exposure on motivated behavior: How apple makes you "Think Different". Consumer Research Journal, 35(1), 21-35. http://dx.doi.org/10.1086/527269

Gole, V. (2009). Powering brand equity through social media. Tata Consultancy Services (TCS), Mumbai.

Grimes, A. (2008). Towards an integrated model of low attention advertising effects: A perceptual-conceptual 
framework. European Journal of Marketing, 42(1/2), 69-86. http://dx.doi.org/10.1108/03090560810840916

Haven, B., Bernoff, J., \& Glass, S. (2007). Marketing's new key metric: Engagement. Forrester Research, Inc.

Hollebeek, L. D. (2011). Demystifying customer brand engagement: exploring the loyalty nexus. Marketing Management Journal, 27(7/8), 785-807. http://dx.doi.org/10.1080/0267257X.2010.500132

Jansen, B. J., Zhang, M., Sobel, K., \& Chowdury, A. (2009, November). Twitter Power: Tweets as Electronic Word of Mouth. Journal of the American Society for Information Science and Technology, 60(11), 2169-2188. http://dx.doi.org/10.1002/asi.21149

Kichatov, V., \& Mihajlovski, N. (2010, June). Social media as a promotional tool-a comparison between political parties and companies (Master Dissetation). Lulea University of Technology, Sweden. Retrieved from http://epubl.ltu.se/1402-1552/2010/055/LTU-DUPP-10055-SE.pdf

Kotler, P., \& Keller, K. L. (2009). Marketing Management (13th ed.). Pearson International Edition, Middle East.

Laroche, M., Kim, C., \& Zhou, L. (1996, October). Brand familiarity and confidence as determinants of purchase intention: An empirical test in a multiple brand context. Business Research Journal, 37(2), 115-120. http://dx.doi.org/10.1016/0148-2963(96)00056-2

Li, C. (2007, June 21). How consumers use social networks. Forrester Research Inc.

Manning-Schaffel, V. (2009, May 25). Why Brands Have an Eye on Facebook? Retrieved from http://www.brandchannel.com/features_effect.asp?pf_id $=479$

Matthes, J., Schemer, C., \& Wirth, W. (2007). More than meets the eye: Investigating the hidden impact of brand placements in television magazines. International Journal of Advertising, 26(4), 477-503.

Miller, K. D., Fabian, F., \& Lin, S. J. (2009). Strategies for online communities. Strategic Management Journal, 30(3), 305-322. http://dx.doi.org/10.1002/smj.735

Moorthi, Y. L. R. (2002). Approach to branding services. Services Marketing Journal, 16(3), 259-274. http://dx.doi.org/10.1108/08876040210427236

Nicholls, W. (2008, February 27). For two sisters, little cakes are a big hit. Washington Post, F01. Retrieved from http://www.washingtonpost.com/wp-dyn/content/article/2008/02/26/AR2008022600703.html

Palmer, A., \& Koenig-Lewis, N. (2009). An experiential, social network-based approach to direct marketing. International Journal of Direct Marketing, 3(3), 162-176. http://dx.doi.org/10.1108/17505930910985116

Pitts, B. G., \& Slattery, J. (2004). An examination of the effect of time on sponsorship awareness levels. Sport Marketing Quarterly Journal, 13, 43-54.

Plummer, J., Cook, B., Diforio, D., Schachter, B., Sokolyanskaya, I., \& Korde, T. (2007). Measures of engagement. Advertising Research Foundation, 2, 1-9. http://dx.doi.org/10.2501/S0021849907070018

Poffé, S. (2010). Thesis: The use of Social Media for a Marketing Manager Hypothesis Generation. Katholieke Universiteit Leuven.

Shim, J. K. (2000). Strategic business forecasting: The complete guide to forecasting real world company performance. CRC Press.

Stokes, R. (2008). E-Marketing: The essential guide to online marketing. Quirk eMarketing (Pty) Ltd.

Thackeray, R., Neiger, B. L., Hanson, C. L., \& McKenzie, J. F. (2008, October). Enhancing promotional strategies within social marketing programs: Use of Web 2.0 Social Media. Health Promotion Practice Journal, 9(4), 338-343. http://dx.doi.org/10.1177/1524839908325335

Weber, L. (2009). Marketing to the Social Web: How digital customer communities build your business. Hoboken, New Jersey: John Wiley and Sons, Inc. http://dx.doi.org/10.1002/9781118258125

Xu, J. B., \& Chan, A. (2010). A conceptual framework of hotel experience and customer-based brand equity. International Journal of Contemporary Hospitality Management, 22(2), 174-193. http://dx.doi.org/10.1108/09596111011018179

Zajonc, R. B. (1968). Attitudinal effects of mere exposure. Journal of Personality and Social Psychology Monographs Supplement, 9(2, Part.2), 1-27. http://dx.doi.org/10.1037/h0025848

\section{Copyrights}

Copyright for this article is retained by the author(s), with first publication rights granted to the journal.

This is an open-access article distributed under the terms and conditions of the Creative Commons Attribution license (http://creativecommons.org/licenses/by/3.0/). 